\title{
Price Transmission Process in Vertical Markets: an Empirical Analysis of Onion Markets in Tamil Nadu State (India)
}

\author{
By Srinivasulu Rajendran ${ }^{1 *}$
}

\begin{abstract}
The objective of the paper is to examine price transmission process between wholesale and retail markets by adopting Asymmetric Price Transmission (APT) Model. The paper has taken a case of Onion ((Allium cepa L.) wholesale and retail markets in Tamil Nadu state, India. The paper used wholesale and retail prices data from secondary sources. The results show that high margin at retail and wholesale levels of prices points to possibility of distortion in prices which may lead to an asymmetric process in the vertical market. The speed and magnitude of price changes and also the type of asymmetry in the vertical market system has identified the presence of both positive and negative asymmetry. With respect to speed, where the markets have shown negative asymmetry, there is evidence of retail prices responding much faster to decrease in wholesale prices than to increases in wholesale prices. Where a positive asymmetry holds, the result is the opposite.
\end{abstract}

Keywords: Vegetables, Asymmetry, Efficiency, Market Integration and Symmetry

\section{Introduction}

In India, persistently high food inflation remains a major concern. High food inflation affects small farmers and the poor consumers the most through inefficient allocation of resources towards production and consumption. The government therefore initiates several initiatives such as tight monetary policy, stock limits, minimum support price, regulated markets, technology mission and market intervention schemes to control inflation. Despite various interventions by government from time to time, not only do the prices of various commodities tend to be volatile, but also price decline at one stage due to increase in the supply is not equal to or comparable with the price decline at the other stage. Vegetable markets are considered to be highly distorted and also major driver for high food inflation in India. Instability in daily prices and large margin between the wholesale and retail prices is a common feature in vegetables markets due to various factors. The large margins are meant to cover risks of loss due to perishable nature of the produce accentuated by the large transaction cost such as weak post-harvest infrastructure, asymmetric price information and transportation cost between markets 
(Minten at al, 2010; Vasisht et al, 2008). These losses leads farmers to face instability in income and prices (Acharya, 2004).

The Asymmetric Price Transmission (APT) process is well researched in the case of many commodities in the developed countries but has less focused in the Indian context except Bathla and Srinivasulu (2011) study. However, these studies were focused mainly on major crops. Therefore, the present paper is an addition to literature. The objective of this paper is to examine price transmission process between wholesale and retail markets by taking a case of one vegetable viz. Onion as prices of vegetables is one of the main drivers behind the persistent high food inflation in India. The analysis is done for major Onion market in Tamil Nadu. The hypothesis is that price transmission in a vertical market system is symmetric which indicates that market is efficient. Both precointegration and error correction techniques have been used to empirically estimate the magnitude of APT between wholesale and retail price of selected fruits and vegetables. The study is divided into four sections. First section presents the conceptual framework used for estimating marketing efficiency through the movement of prices in spatial and vertical marketing systems. The second section focuses on data and methodology. The third section analyses empirical results followed by main findings in the last section.

\section{Conceptual Framework: Pricing Efficiency Through Apt}

Pricing efficiency is a part of the broader framework of marketing efficiency. To achieve efficiency in the marketing system both vertically and spatially, free flow of goods and information over form, space, and time is essential (Barrett 1996). This is also of vital importance for the optimal allocation of resources in the production process. Among many aspects, producers' decisions related to resource allocation are directed by information on market price (Timmer et al. 1983). It is argued that efficient price formation is essential for efficient allocation of resources in a market-directed economy. Literature also suggests that socially inefficient allocation of resources may occur even in competitive markets.

In general, prices are formed efficiently when a large number of buyers and sellers, all with similar access to relevant market information, interact to agree on a price as a basis for exchange. However, literature has shown that many markets have failed because the cost of using the market for a transaction is too high relative to the benefits yields from the transaction. Transactions costs include not only transportation cost but also the consequences of imperfect and asymmetrical information that leads to adverse selection and moral hazards as a consequence of the opportunistic behaviour it allows (Stiglitz and Weiss 1981, Meyer and Von Cramon Taubadel 2004). Often, sources of asymmetry, market failure and inefficient allocation of resources are due to the presence of monopolistic tendency among traders, adjustment and menu cost and public intervention (Meyer and Von Cramon-Taubadel 2004, Vavra and Goodwin 2005, Hassouneh et al. 2012).

Pricing efficiency has been analysed based on correlation between prices in pairs of regions and integration under the broad approach of market integration. However, this approach failed to consider the existence of transaction costs and took co-movement of 
prices as evidence of market integration. In view of advances in time series analysis, several studies have focused on integration between prices across spatial markets using co-integration techniques. The analysis is based on the notion of 'Law of One Price (LOP)' whereby a group of prices move proportionately to each other over time (Ardeni 1989, Baffes 1991, (Ravallion 1986, Alderman 1993, Dercon and Lulseged, 1995, Badiane and Shively 1998, Kumar 2006, Bathla 2008).

These studies have assumed symmetric price response in the sense that a shock of a given magnitude to the central market/one level would elicit the same response in the local markets/second level, regardless of whether the shock reflect a price decrease or increase. The latter aspect is studied within a broad framework of Asymmetric Price Transmission (APT). Peltzman (2000) says that APT is also informally called "rockets and feathers". The author further emphasized the importance and predictability of APT in the context of failure in the economic theory of markets. Meyer and Von CramonTaubadel (2004) have surmised that a possible implication of APT is that "consumers are not benefiting from a price reduction at the producers' level, or producers might not benefit from a price increase at the retail level due to several factors". Some of the factors include market power, imperfect information and tacit collusion among traders.

The term "asymmetric" signifies "the reaction of the price at one level of the marketing chain to a price change at another level depending on whether the initial change is positive or negative" (Von Cramon-Taubadel 1998). According to Peltzman (2000), asymmetry is either positive or negative: "if retail price reacts more fully or rapidly to an increase in farm price than to a decrease, the asymmetry is termed positive". Correspondingly, "negative asymmetry denotes a situation in which retail price reacts more fully or rapidly to a decrease in farm price than to an increase".

\section{Materials and Methods}

The data used for the purpose is collected from secondary sources. Daily wholesale and retail prices of onion crop by market were collected for the period December 2008 to July 2011 from Dynamic Market Intelligence (DMI), which is monitored by the Tamil Nadu Agricultural University and Department of Agricultural Marketing, Government of Tamil Nadu. The series is converted into weekly prices. The APT is analysed for three different price series - nominal, real and seasonally adjusted based on decomposition of prices.

To decompose the price series, the study first separated the seasonal factors from the actual series by adopting moving average method and estimated a de-seasonalized series. Next, the trend factor was eliminated. The remaining residual series contains only the cyclical and irregular factors. This methodology derives from Kenney and Keeping (1962). Based on the seasonally adjusted series, APT has been performed only for the major crops, tomato and onion, for comparison with other series. The daily prices have been converted into weekly prices for the analysis.

The nominal prices have been deflated by price index to convert into real prices using Wholesale Price Index (WPI) and Consumer Price Index (CPI) at constant 2004-5 prices. WPI was sourced from the Office of the Economic Advisor, Government of India; CPI was sourced from the Labour Bureau, Ministry of Labour, Government of India. For 
Onion crop, first, the grades were filtered to retain first-grade category products due to price variation within the markets. Second, the markets were decided on the basis of (i) complete availability of the weekly price data series, (ii) capturing the dynamics of the nature of the price transmission between wholesale and retail prices, and (iii) major terminal markets for Onion. Literature has shown that the nature of price adjustment varies across varieties, perishable nature of crops, geographical condition, weather, and location (Hassan and Simioni 2001, Ward 1982, Perez-Mesa et al. 2010). Price of Onion and nineteen varieties (including hybrid and local varieties) in seven districts have been chosen. Details are given in Appendix Tables A.1. The unit of prices reported as per Rs $/ \mathrm{Kg}$. Several approaches have been employed to test market integration and asymmetry based on price transmission. In this paper, integration between the wholesale and retail prices has been tested using unit root and co-integration technique based on Augmented Dickey-Fuller (ADF), Augmented Engle-Granger (E-G), Cointegrating Regression Durbin Watson (CRDW) test. Once a long-run association between two commodities is established, test for asymmetry is done based on APT through pre-co-integration, cointegration and error correction techniques. There are several variants of these approaches based on the first or second difference in the explanatory variables and/or with and without use of dummies. The most acceptable one for pre-co-integration approach is suggested by Wolffram (1971), adopted by Houck (1977) and later extended by Ward (1982). The most widely used for co-integration-error correction is the one suggested by Von Cramon-Taubadel and Loy (1996). Meyer and Von Cramon Taubadel (2004) suggest the following equation as the starting point, assuming symmetric and linear price transmission (vertical). Pout (retail price) and $\mathrm{Pin}_{t}$ (wholesale price) are the firm's output and input prices in period $t$, also referred to as downstream and upstream prices. It is assumed that Pout $_{t}$ is caused by $\operatorname{Pin}_{t} \cdot{ }^{1}$

Pout $_{t}=\alpha_{0}+\beta_{1}$ Pin $_{t}+\mu_{t}$

Farrell (1952) and subsequently Tweeten and Quance (1969) used this equation in a broader sense of irreversibility. Equation (2) is a translation of their original equation for supply analysis in the context of APT.

Pout $_{t}=\alpha_{0}+\beta_{1}^{+} D^{+}{ }_{t} \operatorname{Pin}_{t}+\beta_{1}^{-} \mathbf{D}_{t}^{-} \mathbf{P i n}_{t}+\varepsilon_{t}$

$\mathrm{D}^{+}{ }_{\mathrm{t}}$ and $\mathrm{D}_{\mathrm{t}}^{-}$are dummy variables. The following two conditions have to be met.

1. $\mathrm{D}_{\mathrm{t}}^{+}=1$ if $\operatorname{Pin}_{\mathrm{t}}>\mathrm{Pin}_{\mathrm{t}-1} ; \mathrm{D}_{\mathrm{t}}^{+}=0$ otherwise.

2. $\mathrm{D}_{\mathrm{t}}^{-}=1$ if $\mathrm{Pin}_{\mathrm{t}}<\mathrm{Pin}_{\mathrm{t}-1} ; \mathrm{D}_{\mathrm{t}}^{-}=0$ otherwise.

Using these dummy variables, the input price is split into two variables: one that includes only increasing input price and another that includes only decreasing price. As a result, two input price adjustment coefficients are estimated (see Equation 2). These are, $\beta_{1}{ }^{+}$ (positive) for the increasing input price phases and $\beta_{1^{-}}$(negative) for the decreasing input price phases. Based on F-test, symmetric price transmission is rejected if $\beta_{1}{ }^{+}$and $\beta_{1}{ }^{-}$are significantly different from one another. Rejection of $\mathrm{H}_{0}$ indicates asymmetry or non-

1 If logarithms of prices are used, a constant relative rather than a constant absolute margin is assumed (Peltzman 2000). 
reversibility in price transmission; its acceptance provides evidence of symmetry (reversibility).

Wolffram (1971) proposed another variable splitting technique that explicitly includes first difference in the equation to be estimated. Houck (1977) proposed a specification (Equation 3) that is similar to Wolffram's but is operationally clearer. It includes only the first difference of the increasing and decreasing phases of $\mathrm{Pin}_{t}$ without summing these, as done by Wolffram (1971).

$\Delta \mathbf{P o u t}_{\mathrm{t}}=\boldsymbol{\alpha}_{0} \mathrm{t}+\boldsymbol{\beta}_{1}{ }^{+} \mathbf{D}^{+}{ }_{\mathrm{t}} \Delta \mathbf{P}_{\mathrm{t}}+\boldsymbol{\beta}_{1^{-}} \mathbf{D}_{\mathrm{t}}^{-} \Delta \mathbf{P i n}_{\mathrm{t}}+\gamma_{\mathrm{t}}$

Ward (1982) extended Houck's specifications by including lags of the exogenous variables:

$\Delta \mathbf{P o u t}_{\mathrm{t}}=\alpha_{0}+\Sigma_{\mathrm{j}=1}^{\mathrm{K}_{\mathrm{j}}}\left(\boldsymbol{\beta}_{1}{ }^{+} \mathbf{D}^{+}{ }_{\mathrm{t}} \Delta \mathbf{P}_{\mathrm{in}-\mathrm{j}+1}\right)+\Sigma^{\mathbf{L}_{\mathrm{j}=1}}\left(\boldsymbol{\beta}_{1^{-}} \mathbf{D}_{\mathrm{t}}^{-} \Delta \mathbf{P}^{\mathrm{in}}{ }_{\mathrm{t}-\mathrm{j}+1}\right)+\gamma_{\mathrm{t}}$

Lag lengths $\mathrm{K}$ and $\mathrm{L}$ can differ, because there is no a priori reason to expect equal lag lengths for the increasing and decreasing phases of price transmission. In many studies, lags are also used to differentiate between the magnitude and speed of price transmission (Boyd and Brorsen, 1988; Hahn, 1990). ${ }^{2}$

Von Cramon-Taubadel and Fahlbusch (1994) pointed out that price series are generally non-stationary and that the 'Houck approach' may not be consistent; that by using the Engle-Granger Representation Theorem, one has to develop an alternative specification for price transmission process. They developed and applied an Error Correction Model (ECM) that incorporates asymmetric adjustment terms for testing APT. Under this approach, equation (1) is estimated first. If the test proves that the equation is not a spurious regression, then $\mathrm{Pin}_{t}$ and Pout ${ }_{t}$ are referred to as being co-integrated and this equation can be considered as an estimate of the long-term equilibrium relationship. Once the variables (two price series) are found to be co-integrated, having long-run equilibrium relationship, an ECT, i.e. lagged residuals from the estimated equation (1) is estimated. The residual series is taken in the ECM as it allows price in one stage (market) to respond to changes in price in the other stage (market) and corrects any deviations from the long-run equilibrium between the two price series that may be left over from previous periods. The ECT is then split into positive and negative components (i.e. positive and negative deviations from the long-term equilibrium - $\mathrm{ECT}^{+}$and $\mathrm{ECT}^{-}$) to enable test for APT as follows.

$$
\Delta \mathbf{P}_{t}^{\text {out }}=\alpha_{0}+\Sigma_{\mathrm{J}=1}^{\mathrm{K}_{1}} \beta_{\mathrm{j}} \Delta \mathbf{P}_{\mathrm{t}-\mathrm{j}+1}+\varphi^{+} \mathrm{ECT}_{\mathrm{t}-1}^{+}+\varphi^{-} \mathrm{ECT}_{\mathrm{t}-1}^{-}+\gamma_{\mathrm{t}}
$$

Further, to allow for more complex dynamic effects, $\Delta \mathrm{Pin}^{\mathrm{in}}$ in equation (5) can also be split into positive and negative components suggested by Meyer and Von Cramon-Taubadel (2004):

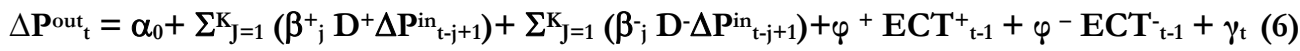

${ }^{2}$ Lag length can be decided based on Akaike's Information Criterion (AIC) criterion and the Schwarz Information Criterion (SIC). One can also proceed with lags until they are statistically significant. 
While $\varphi$ measures adjustment to deviations from long term equilibrium, $\beta$ coefficient provides short-run dynamics. The error correction term allows price in one stage to respond to changes in price in other stage and corrects any deviations from long-run equilibrium between two price series that may be left over from previous periods. In other words, the coefficient indicates speed of adjustment of variables towards equilibrium.

It is evident that the Houck approach is nested in this ECM model. Both equations (5) and (6) are based on linear error correction (i.e. constant parameters $\varphi^{+}$and $\varphi^{-}$), whereby a constant proportion of any deviation from the long-run equilibrium is corrected, regardless of the size of this deviation. ${ }^{3}$ Since co-integration and ECM are based on the idea of a long-run equilibrium which prevents $\mathrm{Pout}_{t}$ and $\mathrm{Pin}_{t}$ from drifting apart, it is possible to consider asymmetry only with respect to the speed of price transmission, but not the magnitude. ${ }^{4} \mathrm{~A}$ joint $\mathrm{F}$-test can be used to determine whether the price transmission process is symmetric or asymmetric: $\mathrm{H}_{0}=\sum \mathrm{K}_{\mathrm{J}=1} \beta^{+}{ }_{\mathrm{j}}=\sum \mathrm{K}_{\mathrm{J}=1} \beta_{\mathrm{j}}$ and $\varphi^{+}=\varphi^{-}$. The estimation procedure could be ordinary least squares or generalized least squares.

\section{Results and Discussion}

The analysis is undertaken using both real and nominal prices and also seasonally adjusted price. However, the results are similar across price category; therefore the study has reported results based on real prices. Onion price is a leading cause of the persistent high food inflation in India. Onion is extensively cultivated in all seasons over a large area throughout Tamil Nadu. Talaivasal, Trichy, Coimbatore, Mettupalayam, Hosur, Chennai and Panruti are major markets for onion in Tamil Nadu.

It is seen from Appendix Table A.2a that irrespective of variety, the average wholesale price of onion varies across markets between Rs. 4.8 and 13.4 per $\mathrm{kg}$, whereas the actual price ranges between Rs. 2.1 and Rs. 31.2. The lowest wholesale prices are reported in Panruti (Bellary Poti) ${ }^{5}$ and Talaivasal (Bellary Small). The highest price is reported in Hosur for Small variety. The highest Coefficient of Variation (CV) was reported in Hosur for Bellary Medium (68.5 per cent); it was the lowest in Chennai for the Small variety. CV indicates that the highest instability in wholesale prices prevails in Hosur; the lowest instability is Chennai. Variation is consistently higher in wholesale than in retail prices.

The retailers' margin is higher in Chennai than in other markets. There is also high markup in Chennai. Clearly, the Chennai market is highly distorted. Despite a fall in the wholesale prices, the retailers in this market sell their produce at higher prices. Average

${ }^{3}$ Several studies (Capps and Sherwell 2005, Balke, Brown and Yucel 1998) have employed variants of the asymmetric error correction model by specifying and introducing in the specified equations varying lag structures, dependent variables, and possible non-linearity in price transmission by allowing higher-order polynomials of ECT to enter into ECM.

${ }^{4}$ APT with respect to magnitude means that there is a permanent difference between positive and negative episodes of transmission. This will, in the long run, cause prices to rise or fall, with the result that they cannot be co-integrated. In this context, Goodwin and Holt (1999) and Goodwin and Piggott (2001) have followed the threshold approach, which considers an intuitively appealing type of ECM in which deviations from the long-run equilibrium between two price series will only lead to price responses if they exceed a specific threshold level.

5 Varieties mentioned in brackets italic format 
wholesale price of Small variety is Rs. 13.0; the retail price is Rs. 24.4. In other words, these retailers earn a margin of 49.2 per cent.

The average retail price varies between Rs. 7.2 and 25.4 and the absolute retail price varies between Rs. 4.1 and Rs. 50.6. The absolute lowest prices are in Panruti; the absolute highest prices are in Chennai. Small variety sells for more than Bellary variety. The former is more in demand but its supply is less. The possibility of wastage and transport cost are also high for this variety as it is mainly procured from other states.

It is seen from Table Appendix A.2b that most of the wholesale and retail price series are integrated in the order of I(0) or I(1). Some varieties in Trichy, Talaivasal, Mettupalayam, Hosur and Panruti have been dropped for the co-integration test due to existence of non-stationary process in the series. Granger Causality Test indicates that in Talaivasal (Bellary Big) retail price is caused by wholesale price; in Coimbatore (Small) both wholesale and retail prices cause each other. In the other markets retail and wholesale prices do not cause each other. Since causality flows from retail prices to wholesales prices in Mettupalayam, this market has been dropped for the APT analysis.

Since all the markets are integrated, pre-co-integration approach has been dropped. ECM results are presented in Table 1a. The resultant elasticities are presented in Table 1b. It is seen from the results that almost all markets have positive asymmetry except Chennai market for Nagar and Solapur varieties. Retail prices respond to wholesale prices almost equally in Hosur (Small), Talaivasal (Bellary Medium) and Mettupalayam (Small Medium) but the coefficient of ECT is significant (Table 1a). ECT+, showing significant and negative sign, indicates that retail prices react more rapidly when the margin is stretched than when it is squeezed.

Only in Chennai (Small) market, the retailers' reaction is extremely high to $\mathrm{D}+$ than to D- (Table 7.4b). Hence, the presence of strong market power is more likely in Chennai than in other markets due to possible tacit collusion among retailers. On the other hand, Hosur (Small and Small Medium), Coimbatore (Small) and Mettupalayam (Small and Medium) are comparatively efficient markets. Better diffusion of market information and comparatively low menu cost in these markets results in weak market power among the retailers.

\section{Conclusion and Policy Suggestions}

It is found that Chennai, Ottanchatram and Coimbatore F\&V markets have high gaps between wholesale and retail prices and prices are also instable. It may in order to cover risk of loss due to the perishable nature of the produce, which is accentuated by large transaction cost which includes weak post-harvest infrastructure, imperfect price information and high transportation cost between markets. There may also be tacit collusion among the retailers to stabilize their profit (Ward 1982, Minten et al. 2010, Vasisht et al. 2008). In contrast, Hosur, Trichy, Panruti and Talaivasal markets have low price mark-up and margins. In terms of asymmetry, these districts have shown better performance for most of the vegetable crops as compared to other markets. Chennai is the most inefficient among all.

High margin at two levels of prices also points to possibility of distortion in prices which may lead to an asymmetric process in the vertical market. The speed and magnitude of 
price changes and also the type of asymmetry in the vertical market system has identified the presence of both positive and negative asymmetry. With respect to speed, where the markets have shown negative asymmetry, there is evidence of retail prices responding much faster to $\mathrm{D}$ - than to $\mathrm{D}+$ (i.e. $+\mathrm{D}<\mathrm{D}$-). Where a positive asymmetry holds, the result is the opposite (i.e. $\mathrm{D}+>\mathrm{D}-$ ).

Sometimes, positive asymmetry is usually related to the retailer's bargaining power. Possible reasons for negative asymmetry are: (i) where profit margins are high, marginal decline in price may not have a major impact on profitability; (ii), they occur in markets where there is excess supply over demand, which leads retailers to sell soon even if there is a fall in price. This result is aligned with Ward (1982). This could also vary across varieties. For instance, the distortion happens mostly in hybrid varieties, which are relatively less perishable than local varieties, which are also traded largely outside and within the state. In addition, both wholesalers and retailers have market power in adjudging prices, mainly because they can store the hybrid variety. Overall results show asymmetry in the prices of onion markets. Markets in Hosur, Trichy and Talaivasal performed better, and Chennai market is found to be the most inefficient. This paper suggests that transparency in price formation is necessary at each stages of value chain system. Secondly, transaction cost in vertical marketing system must be reduced by linking each actor in the value chain through increasing access to infrastructure and markets on time.

\section{Conflict of Interest}

The author have not declared any conflict of interest.

\section{References}

Acharya SS (2004). Agricultural Marketing - State of the Indian Farmer: A Millennium Study, 27 Volumes at a Glance, Academic Foundation, Ministry of Agriculture, Government of India, New Delhi

Alderman H (1993). Intercommodity Price Transmittal: Analysis of Food Markets in Ghana, Oxford Bulletin of Economics and Statistics, Department of Economics, University of Oxford, 55(1): 43-64, February

Ardeni PG (1989). Does The Law Of One Price Really Hold For Commodity Prices?, American Journal of Agricultural Economics, 71: 661-669

Badiane O, Shively, GE (1998). Spatial Integration, Transport Costs, and The Response of Local Prices to Policy Changes in Ghana, Journal of Development Economics, Elsevier, 56(2): 411-431, August

Baffes J (1991). Some Further Evidence on the Law of One Price: The Law of One Price Still Holds, American Journal of Agricultural Economics, 73, 1264-1273

Balke NS, Brown SPA and Yucek MK (1998). Crude Oil and Gasoline Price: An Asymmetric Relationship?,Federal Reserve Bank of Dalles, Economic Review, First Quarter, pp. 2-11

Barrett C (1996). Market Analysis Methods: Are Our Enriched Toolkits Well Suited to Enlivened Markets?, American Journal of Agricultural Economics, 78: 825-9

Bathla S (2008). Agriculture Reforms and Market Integration: A Spatial Analysis of Food and Non-Food Commodities, Journal of Social and Economic Development, 10, No. 2, July-December

Bathla S, Srinivasulu R (2011). Price Transmission and Asymmetry: An Empirical Analysis of Indian Groundnut Seed and Oil Markets, Indian Journal of Agricultural Economics, October-December, 2011

Capps Oral Jr., Pablo S (2005). Spatial Asymmetry in Farm-Retail Price Transmission Associated with Fluid Milk Products, Paper prepared for presentation at the American Agricultural Economics Association Annual Meeting, Providence, Rhode Island 
Dercon S, Ayalew L (1995). Smuggling and Supply Response: Coffee in Ethiopia, World Development, Elsevier, 23(10):1795-1813, October

Farrel MJ (1952) Irreversible Demand Functions, Econometrica, 20:171-186

Farrell MJ (1957). The Measurement of Productive Efficiency, Journal of the Royal Statistical Society, 120 (3): 253-281

Goodwin B K, Holt M T (1999). Asymmetric Adjustment and Price Transmission in the U.S. Beef Sector, American Journal of Agricultural Economics, 81: 630-637

Goodwin BK, Piggott N E (2001). Spatial Market Integration in the Presence of Threshold Effects, American Journal of Agricultural Economics, 83(2): 302-317

Hassan D, Simioni M (2001). Price Linkage and Transmission Between Shippers and Retailers in The Frengh Vegetable Channel, Economics Working Paper Archive (Toulouse) 18, French Institute for Agronomy Research (INRA). Economics Laboratory in Toulouse (ESR Toulouse)

Hassouneh I, Von Cramon-Taubadel, S, Serra T, Gil JM (2012). Recent Developments in the Econometric Analysis of Price Transmission, TRANSFOP (Transparency of Food Pricing). Working Paper No. 2, www.transfop.eu

Houck PJ (1977). An Approach to Specifying and Estimating Nonreversible Functions, American Journal of Agricultural Economics, 59, No. 3 (Aug.): 570-572

Kenney JF, Keeping ES (1962). 'The -Statistics', Mathematics of Statistics, (3rd ed.) Princeton, NJ: Van Nostrand

Kumar P (2006). Inter Commodity Price Linkage in India: A Case of Foodgrains, Oilseeds and Edible Oils, Journal of International and Area Studies, 13, No. 1, June

Meyer J, Von Cramon-Taubadel S (2004). Asymmetric Price Transmission: A Survey, Journal of Agricultural Economics, 55 (3). 581-611

Minten B (2010). Technology Adoption, Agricultural Productivity, and Road Infrastructure in Bhutan, Policy \& Planning Division, Ministry of Agriculture and Forests, SDC-IFPRI-Bhutan Project on Agricultural and Food Policy Research and Capacity Strengthening, August

Pavel V, Barry KG (2005). Analysis of Price Transmission along the Food Chain, OECD Food, Agriculture and Fisheries Working Papers 3, OECD Publishing

Peltzman S (2000). Prices Rise Faster Than They Fall, Journal of Political Economy, 108: 466-502

Perez-Mesa1 JC, Galdeano-Gomez E, Aznar-Sanchez JA (2010). Retail Price Rigidity in Perishable Food Products: A Case Study, Spanish Journal of Agricultural Research, 8(4): 895-907

Ravallion M (1986). Testing Market Integration, American Journal of Agricultural Economics, 68, No. 1: 102-9

Stiglitz, JE, Andrew W (1981). Credit Rationing in Markets with Imperfect Information, American Economic Review, 71: 393-410

Tweeten LG, Quance CL (1969) Positivistic Measures of Aggregate Supply Elasticities: Some New Approaches, American Journal of Agricultural Economics, 51: 342-352

Vasisht AK, Seema B, Singh DR, Bhardwaj SP, Prawin A (2008). Price Behaviour in Fruits and Vegetables Markets: Cointegration and Error Correction Analysis, Summaries, Indian Journal of Agricultural Economics, 63, No. 3, July-September

Von Cramon-Taubadel, S (1998). Price Asymmetric Price Transmission with the Error Correction Representation: An Application to the German Pork Market, European Review of Agricultural Economics, 25: 1-18

Von Cramon-Taubadel S, Loy J P (1996). Price Asymmetry in the International Wheat Market: Comment, Canadian Journal of Agricultural Economics, 44: 311-317

Von Cramon-Taubadel S, Loy JP (1999). The Identification of Asymmetric Price Transmission Processes with Integrated Time Series, The Journal of Economics and Statistics, 218 (1-2): 85-106

Ward RW (1982). Asymmetry in Retail, Wholesale and Shipping Point Pricing for Fresh Vegetables, American Journal of Agricultural Economics, 62: 205-212

Wolffram R (1971). Positivistic Measures of Aggregate Supply Elasticities - Some New Approaches -Some Critical Notes, American Journal of Agricultural Economics, 53: 356-356 


\section{Appendix 1}

Table 1a: Empirical Results of APT based on ECM Approach for Onion (at 2004-5 prices)

\begin{tabular}{|c|c|c|c|c|c|c|c|c|c|c|c|c|}
\hline \multirow{2}{*}{$\begin{array}{l}\text { Depen } \\
\text { dent } \\
\text { Variab } \\
\text { le: } \\
\text { Retail } \\
\text { Price }\end{array}$} & $\begin{array}{l}\text { Ho } \\
\text { sur }\end{array}$ & $\begin{array}{l}\text { Hos } \\
\text { ur }\end{array}$ & $\begin{array}{l}\text { Coimb } \\
\text { atore }\end{array}$ & $\begin{array}{l}\text { Mett } \\
\mathbf{u} \\
\text { Pala } \\
\text { yam } \\
\end{array}$ & $\begin{array}{l}\text { Mett } \\
\mathbf{u} \\
\text { palay } \\
\text { am } \\
\end{array}$ & $\begin{array}{l}\text { Tri } \\
\text { chy }\end{array}$ & $\begin{array}{l}\text { Talaiv } \\
\text { asal }\end{array}$ & $\begin{array}{l}\text { Talaiv } \\
\text { asal }\end{array}$ & $\begin{array}{l}\text { Talaiv } \\
\text { asal }\end{array}$ & $\begin{array}{l}\text { Che } \\
\text { nnai }\end{array}$ & $\begin{array}{l}\text { Che } \\
\text { nnai }\end{array}$ & $\begin{array}{l}\text { Che } \\
\text { nnai }\end{array}$ \\
\hline & $\begin{array}{l}\text { Sm } \\
\text { all }\end{array}$ & $\begin{array}{l}\text { Smal } \\
1 \\
\text { Medi } \\
\text { um }\end{array}$ & $\begin{array}{l}\text { Small } \\
\text { Fresh }\end{array}$ & $\begin{array}{l}\text { Smal } \\
1\end{array}$ & $\begin{array}{l}\text { Smal } \\
1 \\
\text { Medi } \\
\text { um }\end{array}$ & $\begin{array}{l}\text { Sm } \\
\text { all }\end{array}$ & $\begin{array}{l}\text { Bellar } \\
\text { y } \\
\text { Small } \\
\end{array}$ & $\begin{array}{l}\text { Bellar } \\
\mathrm{y}\end{array}$ & $\begin{array}{l}\text { Bellar } \\
\text { y } \\
\text { Medi } \\
\text { um } \\
\end{array}$ & $\begin{array}{l}\text { Nag } \\
\text { ar }\end{array}$ & $\begin{array}{l}\text { Smal } \\
1\end{array}$ & $\begin{array}{l}\text { Sola } \\
\text { pur }\end{array}$ \\
\hline & \multicolumn{12}{|c|}{ ECM Approach } \\
\hline Const & $\begin{array}{l}0.18 \\
(2.0)^{*} \\
* \\
\end{array}$ & $\begin{array}{c}0.22 \\
(2.3)^{* *}\end{array}$ & $\begin{array}{l}-0.17 \\
-0.74\end{array}$ & $\begin{array}{l}0.04 \\
0.23\end{array}$ & $\begin{array}{l}0.12 \\
0.78\end{array}$ & $\begin{array}{l}-0.2 \\
-1.47\end{array}$ & $\begin{array}{l}0.03 \\
0.26\end{array}$ & $\begin{array}{l}0.04 \\
0.31\end{array}$ & $\begin{array}{c}0.33 \\
(2.1)^{* *}\end{array}$ & $\begin{array}{l}-0.01 \\
-0.03\end{array}$ & $\begin{array}{c}-0.98 \\
(-2.1)^{* *}\end{array}$ & $\begin{array}{l}-0.01 \\
-0.01\end{array}$ \\
\hline $\begin{array}{l}\mathrm{D}+ \\
\text { Wholes } \\
\text { ale } \\
(\mathrm{SR}+) \\
\end{array}$ & $\begin{array}{c}1.14 \\
(33.6 \\
)^{*} \\
\end{array}$ & $\begin{array}{c}1.2 \\
(26.5) \\
*\end{array}$ & $\begin{array}{l}0.78 \\
(6.5)^{*}\end{array}$ & $\begin{array}{c}1.33 \\
\\
(14.7) \\
*\end{array}$ & $\begin{array}{c}1.12 \\
(15.5) \\
*\end{array}$ & $\begin{array}{c}1.3 \\
(17.4 \\
)^{*} \\
\end{array}$ & $\begin{array}{c}1.5 \\
(19.7)^{*}\end{array}$ & $\begin{array}{c}1.21 \\
(17.7)^{*}\end{array}$ & $\begin{array}{c}1.26 \\
(18.8)^{*}\end{array}$ & $\begin{array}{c}1.35 \\
(12.0) \\
*\end{array}$ & $\begin{array}{c}1.03 \\
(5.1)^{*}\end{array}$ & $\begin{array}{c}1.25 \\
(10.7) \\
*\end{array}$ \\
\hline $\begin{array}{l}\mathrm{D}+ \\
\text { lag1 }\end{array}$ & - & - & $\begin{array}{l}0.32 \\
(2.5)^{* *}\end{array}$ & - & - & - & $\begin{array}{c}0.2 \\
(2.5)^{*}\end{array}$ & - & - & $\begin{array}{c}0.09 \\
0.7\end{array}$ & $\begin{array}{c}0.48 \\
(2.5)^{* *}\end{array}$ & $\begin{array}{l}-0.11 \\
-0.76\end{array}$ \\
\hline $\begin{array}{l}\mathrm{D}+ \\
\text { lag2 }\end{array}$ & - & - & - & - & - & - & - & - & - & $\begin{array}{l}-0.51 \\
(-4.3)^{*}\end{array}$ & - & $\begin{array}{c}-0.3 \\
(-2.3)^{* *}\end{array}$ \\
\hline $\begin{array}{l}\text { (Cum } \\
+)\end{array}$ & 1.14 & 1.2 & 1.1 & 1.33 & 1.12 & 1.3 & 1.7 & 1.21 & 1.26 & 0.94 & 1.51 & 0.84 \\
\hline $\begin{array}{l}\text { D- } \\
\text { Wholes } \\
\text { ale } \\
\text { (SR-) }\end{array}$ & $\begin{array}{c}1.12 \\
(24.5) \\
*\end{array}$ & $\begin{array}{c}1.05 \\
(17.9)^{*}\end{array}$ & $\begin{array}{l}0.71 \\
(5.3)^{*}\end{array}$ & $\begin{array}{c}1.0 \\
(12.0)^{*}\end{array}$ & $\begin{array}{c}1.1 \\
(12.1)^{*}\end{array}$ & $\begin{array}{c}0.93 \\
(15.8) \\
*\end{array}$ & $\begin{array}{c}1.49 \\
(12.1)^{*}\end{array}$ & $\begin{array}{c}0.98 \\
(11.5)^{*}\end{array}$ & $\begin{array}{c}1.15 \\
(14.1)^{*}\end{array}$ & $\begin{array}{l}0.64 \\
(5.2)^{*}\end{array}$ & $\begin{array}{l}0.79 \\
(4.6)^{*}\end{array}$ & $\begin{array}{l}0.55 \\
(3.7)^{*}\end{array}$ \\
\hline D-lag 1 & - & - & $\begin{array}{l}0.28 \\
1.97\end{array}$ & - & - & - & - & - & $\begin{array}{l}0.15 \\
1.84\end{array}$ & $\begin{array}{c}0.4 \\
(3.2)^{*}\end{array}$ & - & $\begin{array}{c}0.63 \\
(4.3)^{*}\end{array}$ \\
\hline $\begin{array}{l}\text { (Cum } \\
-)\end{array}$ & 1.12 & 1.05 & 0.99 & 1.0 & 1.1 & 0.93 & 1.49 & 0.98 & 1.3 & 1.04 & 0.79 & 1.18 \\
\hline $\begin{array}{l}\text { Lagge } \\
\text { d ECT } \\
+\end{array}$ & $\begin{array}{c}-0.38 \\
(- \\
3.5)^{*} \\
\end{array}$ & $\begin{array}{l}-0.68 \\
(-4.7)^{*}\end{array}$ & $\begin{array}{l}-0.1 \\
-1.21\end{array}$ & $\begin{array}{l}-0.64 \\
(-4.6)^{*}\end{array}$ & $\begin{array}{c}-0.6 \\
(-3.8)^{*}\end{array}$ & $\begin{array}{c}-0.33 \\
(- \\
3.4)^{*} \\
\end{array}$ & $\begin{array}{l}-0.33 \\
(-2.7)^{*}\end{array}$ & $\begin{array}{l}-0.54 \\
(-3.9)^{*}\end{array}$ & $\begin{array}{l}-0.55 \\
(-4.1)^{*}\end{array}$ & $\begin{array}{l}-0.03 \\
-0.66\end{array}$ & $\begin{array}{l}-0.04 \\
-0.49\end{array}$ & $\begin{array}{l}-0.02 \\
-0.39\end{array}$ \\
\hline $\begin{array}{l}\text { Lagge } \\
\text { d ECT } \\
\text { - }\end{array}$ & $\begin{array}{l}0.02 \\
0.22\end{array}$ & $\begin{array}{l}0.06 \\
0.53\end{array}$ & $\begin{array}{l}-0.22 \\
-1.84\end{array}$ & $\begin{array}{l}-0.18 \\
-1.03\end{array}$ & $\begin{array}{l}-0.27 \\
-1.43\end{array}$ & $\begin{array}{l}-0.21 \\
-1.53\end{array}$ & $\begin{array}{l}-0.14 \\
-0.93\end{array}$ & $\begin{array}{l}-0.21 \\
-1.44\end{array}$ & $\begin{array}{l}0.09 \\
0.65\end{array}$ & $\begin{array}{l}-0.06 \\
-0.8\end{array}$ & $\begin{array}{c}-0.28 \\
(-2.3)^{* *}\end{array}$ & $\begin{array}{l}-0.12 \\
-1.48\end{array}$ \\
\hline $\mathrm{N}$ & 104 & 104 & 128 & 103 & 103 & 124 & 104 & 105 & 93 & 131 & 135 & 131 \\
\hline F Stat & $\begin{array}{c}583 . \\
9\end{array}$ & 329.1 & 27.9 & 130.9 & 128.3 & $\begin{array}{c}240 . \\
8\end{array}$ & 140.7 & 160.8 & 150.2 & 42.5 & 17.9 & 36.0 \\
\hline $\begin{array}{l}\text { Prob } \\
>\mathrm{F}\end{array}$ & 0 & 0 & 0 & 0 & 0 & 0 & 0 & 0 & 0 & 0 & 0 & 0 \\
\hline R-sqrt & 0.96 & 0.93 & 0.58 & 0.84 & 0.84 & 0.89 & 0.88 & 0.87 & 0.9 & 0.71 & 0.41 & 0.67 \\
\hline Adj R & 0.96 & 0.93 & 0.56 & 0.84 & 0.83 & 0.89 & 0.87 & 0.86 & 0.89 & 0.69 & 0.39 & 0.65 \\
\hline $\begin{array}{l}\text { Root } \\
\text { MSE }\end{array}$ & 0.53 & 0.56 & 1.25 & 0.97 & 0.8 & 0.79 & 0.72 & 0.9 & 0.83 & 1.42 & 2.42 & 1.52 \\
\hline $\begin{array}{l}\text { Joint F } \\
\text { Test: }\end{array}$ & 7.43 & 13.11 & 3.85 & 16.93 & 13.84 & 11.5 & 7.44 & 14.21 & 10.07 & 1.38 & 4.84 & 2.21 \\
\hline
\end{tabular}


Table 1b: Elasticities of Price Transmission based on ECM Approach for Onion (At 2004-5 Prices)

\begin{tabular}{|l|l|l|l|l|l|}
\hline Market & Variety & $\mathrm{D}+(\mathrm{SR}+)$ & $\mathbf{( C u m u l a t i v e ~ L R ~}+)$ & $\mathrm{D}-(\mathrm{SR}-)$ & (Cumulative LR -) \\
\hline Hosur & Small & 0.88 & $\mathbf{0 . 8 8}$ & 0.86 & $\mathbf{0 . 8 6}$ \\
\hline Hosur & Small Medium & 0.89 & $\mathbf{0 . 8 9}$ & 0.78 & $\mathbf{0 . 7 8}$ \\
\hline Coimbatore & Small Fresh & 0.50 & $\mathbf{0 . 7 0}$ & 0.45 & $\mathbf{0 . 6 3}$ \\
\hline Mettupalayam & Bellary Pune & 0.71 & $\mathbf{0 . 9 1}$ & 0.81 & $\mathbf{0 . 8 1}$ \\
\hline Mettupalayam & Small & 0.92 & $\mathbf{0 . 9 2}$ & 0.70 & $\mathbf{0 . 7 0}$ \\
\hline Mettupalayam & Small Medium & 0.75 & $\mathbf{0 . 7 5}$ & 0.74 & $\mathbf{0 . 7 4}$ \\
\hline Trichy & Small & 1.00 & $\mathbf{1 . 0 0}$ & 0.71 & $\mathbf{0 . 7 1}$ \\
\hline Talaivasal & Bellary Small & 0.90 & $\mathbf{1 . 0 2}$ & 0.89 & $\mathbf{0 . 8 9}$ \\
\hline Talaivasal & Bellary & 0.87 & $\mathbf{0 . 8 7}$ & 0.70 & $\mathbf{0 . 7 0}$ \\
\hline Talaivasal & Bellary Medium & 0.83 & $\mathbf{0 . 8 3}$ & 0.76 & $\mathbf{0 . 8 6}$ \\
\hline Chennai & Nagar & 0.69 & $\mathbf{0 . 4 7}$ & 0.32 & $\mathbf{0 . 5 3}$ \\
\hline Chennai & Small & 0.53 & $\mathbf{0 . 7 8}$ & 0.40 & $\mathbf{0 . 4 0}$ \\
\hline Chennai & Solapur & 0.64 & $\mathbf{0 . 4 3}$ & 0.28 & $\mathbf{0 . 6 0}$ \\
\hline
\end{tabular}

* Granger Test indicates wholesale price causes retail price.

LR: Long Run; SR: Short Run

\section{APPENDIX 2 TABLES}

Table A.1: Onion: Study period, markets and varieties

\begin{tabular}{|c|c|c|c|c|}
\hline $\begin{array}{l}\text { S. } \\
\text { No }\end{array}$ & Market & Variety & Year & Obs \\
\hline \multirow{2}{*}{1} & \multirow{2}{*}{ Trichy } & Bellary, Old Bellary & $12 / 22 / 2008$ to $04 / 11 / 20011$ & 121 \\
\hline & & Small, Small Grade 1 & $12 / 22 / 2008$ to $05 / 09 / 2011$ & 125 \\
\hline \multirow{4}{*}{2} & \multirow{4}{*}{$\begin{array}{l}\text { Talaivasal } \\
\text { Salem }\end{array}$} & Bellary and Bellary Big & $07 / 20 / 2009$ to $07 / 25 / 2011$ & 106 \\
\hline & & Bellary-Medium & $10 / 05 / 2009$ to $07 / 25 / 2011$ & 95 \\
\hline & & Bellary-Small & $07 / 20 / 2009$ to $07 / 25 / 2011$ & 106 \\
\hline & & Small-New & $07 / 20 / 2009$ to $07 / 25 / 2011$ & 106 \\
\hline \multirow{3}{*}{3} & \multirow{3}{*}{ Panruti } & Bellary and Bellary Big & $07 / 27 / 2009$ to $07 / 25 / 2011$ & 105 \\
\hline & & Bellary-Medium & $07 / 27 / 2009$ to $07 / 25 / 2011$ & 105 \\
\hline & & Bellary-Podi & $07 / 27 / 2009$ to $07 / 25 / 2011$ & 105 \\
\hline \multirow{3}{*}{4} & \multirow{3}{*}{ Mettupalayam } & Small & $08 / 03 / 2009$ to $07 / 25 / 2011$ & 104 \\
\hline & & Small Medium & $08 / 03 / 2009$ to $07 / 25 / 2011$ & 104 \\
\hline & & Bellary Pune & $08 / 03 / 2009$ to $07 / 25 / 2011$ & 104 \\
\hline 5 & Coimbatore & Small Fresh & $12 / 15 / 2008$ to $06 / 06 / 2011$ & 130 \\
\hline \multirow{4}{*}{6} & \multirow{4}{*}{ Hosur } & Bellary & $07 / 27 / 2009$ to $07 / 25 / 2011$ & 105 \\
\hline & & Bellary-Medium & $07 / 27 / 2009$ to $07 / 25 / 2011$ & 105 \\
\hline & & Small & $07 / 27 / 2009$ to $07 / 25 / 2011$ & 105 \\
\hline & & Small-Medium & $07 / 27 / 2009$ to $07 / 25 / 2011$ & 105 \\
\hline \multirow{3}{*}{7} & \multirow{3}{*}{ Chennai } & Nagar and Nagar Old & $01 / 05 / 2009$ to $07 / 25 / 2011$ & 134 \\
\hline & & Small & $12 / 15 / 2008$ to $07 / 25 / 2011$ & 137 \\
\hline & & Solapur and Old & $01 / 05 / 2009$ to $07 / 25 / 2011$ & 134 \\
\hline
\end{tabular}


Table A.2a: Descriptive Statistics for Wholesale and Retail Real Prices of Onion (at 2004-5 prices) (December 2008 to July 2011) (Rs/Kg)

\begin{tabular}{|c|c|c|c|c|c|c|c|}
\hline Real Price Series & Variety & Mean & Min & Max & $\mathrm{CV}$ & $\begin{array}{l}\text { Retailer's } \\
\text { Margin (\%) } \\
\end{array}$ & $\begin{array}{l}\text { Total Mark-up } \\
(\%)\end{array}$ \\
\hline \multicolumn{8}{|l|}{ Trichy } \\
\hline Retail & Bellary, Old Bellary & 12.8 & 6.9 & 32 & 41.9 & 24.6 & 32.6 \\
\hline Wholesale & Bellary, Old Bellary & 9.6 & 4.2 & 24.8 & 48.1 & & \\
\hline Retail & Small, Small Grade 1 & 15.2 & 7.8 & 28.7 & 23.1 & 23.2 & 30.1 \\
\hline Wholesale & Small, Small Grade 1 & 11.7 & 5.4 & 20.8 & 27.2 & & \\
\hline \multicolumn{8}{|c|}{ Talavasal-Salem District } \\
\hline Retail & Bellary and Bellary Big & 14.2 & 8.7 & 41.6 & 51.1 & 28.1 & 39 \\
\hline Wholesale & Bellary and Bellary Big & 10.2 & 4.6 & 31.2 & 57.5 & & \\
\hline Retail & Bellary-Medium & 11.4 & 6.7 & 35.5 & 49.3 & 34 & 51.4 \\
\hline Wholesale & Bellary-Medium & 7.6 & 3.5 & 25.5 & 53.7 & & \\
\hline Retail & Bellary-Small & 8.3 & 5 & 26.5 & 51.2 & 40.2 & 67.1 \\
\hline Wholesale & Bellary-Small & 4.9 & 3 & 15.1 & 47.0 & & \\
\hline Retail & Small-New & 15.8 & 6.2 & 35.6 & 36.1 & 45.7 & 84 \\
\hline Wholesale & Small-New & 8.6 & 4.4 & 14.4 & 28.7 & & \\
\hline \multicolumn{8}{|c|}{ Mettupalayam - Ooty district } \\
\hline Retail & Small & 16.2 & 8.7 & 32.2 & 28.9 & 30.6 & 44.2 \\
\hline Wholesale & Small & 11.3 & 5.2 & 22.4 & 34.3 & & \\
\hline Retail & Small Medium & 13.6 & 7.6 & 32.7 & 38.1 & 33.1 & 49.4 \\
\hline Wholesale & Small Medium & 9.1 & 3.9 & 25.3 & 47.0 & & \\
\hline Retail & Bellary Pune & 13.1 & 5.9 & 34.7 & 50.1 & 28.4 & 39.7 \\
\hline Wholesale & Bellary Pune & 9.3 & 4 & 25.7 & 55.4 & & \\
\hline \multicolumn{8}{|l|}{ Coimbatore } \\
\hline Retail & Small Fresh & 17.8 & 9.1 & 38.1 & 28.8 & 36.2 & 56.6 \\
\hline Wholesale & Small Fresh & 11.3 & 5.3 & 23.4 & 29.2 & & \\
\hline \multicolumn{8}{|l|}{ Hosur } \\
\hline Retail & Bellary & 12.3 & 6.2 & 36.7 & 54.8 & 25.6 & 34.5 \\
\hline Wholesale & Bellary & 9.1 & 4.1 & 28.5 & 59.2 & & \\
\hline Retail & Bellary-Medium & 9.8 & 4.8 & 32.6 & 62.5 & 28.4 & 39.6 \\
\hline Wholesale & Bellary-Medium & 7.0 & 2.8 & 25.3 & 68.5 & & \\
\hline Retail & Small & 17.5 & 9.6 & 33.1 & 29.1 & 23.1 & 30 \\
\hline Wholesale & Small & 13.4 & 5.8 & 26.2 & 31.4 & & \\
\hline Retail & Small-Medium & 14.3 & 7.8 & 27.1 & 33.1 & 25.7 & 34.6 \\
\hline Wholesale & Small-Medium & 10.6 & 4.6 & 21 & 36.8 & & \\
\hline \multicolumn{8}{|l|}{ Chennai } \\
\hline Retail & Nagar and Nagar Old & 17.6 & 7.4 & 50.6 & 44.6 & 49.2 & 97 \\
\hline Wholesale & Nagar and Nagar Old & 8.9 & 3.8 & 30.4 & 56.4 & & \\
\hline Retail & Small & 25.4 & 15.9 & 41.8 & 21.8 & 48.8 & 95.1 \\
\hline Wholesale & Small & 13.0 & 6.3 & 25.6 & 27.9 & & \\
\hline Retail & Solapur and Old & 17.7 & 7.4 & 50.6 & 43.6 & 49.1 & 96.6 \\
\hline Wholesale & Solapur and Old & 9.0 & 3.8 & 30.5 & 55.6 & & \\
\hline \multicolumn{8}{|l|}{ Panruti } \\
\hline Retail & Bellary and Bellary Big & 12.5 & 7.1 & 37.5 & 53.1 & 24.8 & 33 \\
\hline Wholesale & Bellary and Bellary Big & 9.4 & 3.7 & 27.2 & 53.3 & & \\
\hline Retail & Bellary-Medium & 9.7 & 5.4 & 29.6 & 50.1 & 28.0 & 38.9 \\
\hline Wholesale & Bellary-Medium & 7.0 & 3.2 & 20.6 & 49.0 & & \\
\hline Retail & Bellary-Podi & 7.2 & 4.1 & 20.7 & 47.3 & 33.7 & 50.9 \\
\hline Wholesale & Bellary-Podi & 4.8 & 2.1 & 12.9 & 46.7 & & \\
\hline
\end{tabular}

* CV stands for Coefficient of V ariation (\%); exchange rate 1 USD $=61.00$ 
Table A.2b: Co-integration Test for Wholesale and Retail Prices (at 2004-5 prices) of Onion based on Augmented Engle-Granger Test and Granger Causality Test

\begin{tabular}{|c|c|c|c|c|c|c|c|c|}
\hline \multicolumn{6}{|c|}{ Co-integration Test for series } & \multicolumn{3}{|c|}{ Granger Causality Test } \\
\hline Varieties & $\begin{array}{l}\text { E-G } \\
\text { Test }\end{array}$ & $\begin{array}{l}\text { Augment } \\
\text { ed E-G } \\
\text { Test }\end{array}$ & $\begin{array}{l}\text { CRD } \\
\mathrm{W} \\
\text { Test } \\
\end{array}$ & $\begin{array}{l}\text { Integrated } \\
\text { Order } \\
\text { Process of } \\
\text { series }\end{array}$ & $\begin{array}{l}\text { Co } \\
\text {-int }\end{array}$ & $\begin{array}{l}\mathrm{WP} \\
\rightarrow \mathrm{RP}\end{array}$ & $\begin{array}{l}\mathrm{RP} \rightarrow \\
\mathrm{WP}\end{array}$ & Lag \\
\hline \multicolumn{9}{|l|}{ Trichy } \\
\hline $\begin{array}{l}\text { Small, Small Grade } 1 \text { and } \\
\text { Small old }\end{array}$ & $(-6.05)^{*}$ & $(-5.25)^{*}$ & 0.9 & $\mathrm{I}(0)$ & Y & 1.11 & 0.8 & 2 \\
\hline \multicolumn{9}{|l|}{ Talavasal-Salem District } \\
\hline Bellary and Bellary Big & $(-3.98)^{*}$ & $(-3.77)^{*}$ & 0.52 & $\mathrm{I}(1)$ & $\mathrm{Y}$ & $(8.61)^{*}$ & 1.96 & 1 \\
\hline Bellary-Medium & $(-3.09)^{*}$ & $(-3.23)^{*}$ & 0.35 & $\mathrm{I}(0)$ & $\mathrm{Y}$ & 0.01 & 0.89 & 2 \\
\hline Bellary-Small & $(-3.67)^{*}$ & $(-3.98)^{*}$ & 0.45 & $\mathrm{I}(0)$ & $\mathrm{Y}$ & 0.34 & 1.45 & 2 \\
\hline \multicolumn{9}{|l|}{ Mettupalayam - Ooty district } \\
\hline Small & $(-5.85)^{*}$ & $(-5.03)^{*}$ & 0.99 & $\mathrm{I}(1)$ & $\mathrm{Y}$ & 2.52 & 1.62 & 2 \\
\hline Small Medium & $(-5.26)^{*}$ & $(-4.78)^{*}$ & 0.87 & $\mathrm{I}(1)$ & $\mathrm{Y}$ & 0.29 & $(4.33)^{* *}$ & 2 \\
\hline \multicolumn{9}{|l|}{ Coimbatore } \\
\hline Small Fresh & $(-4.81)^{*}$ & $(-4.17)^{*}$ & 0.61 & $\mathrm{I}(0)$ & $\mathrm{Y}$ & $\begin{array}{l}(10.82) \\
* \\
\end{array}$ & $(5.29) *$ & 2 \\
\hline \multicolumn{9}{|l|}{ Hosur } \\
\hline Small & $(-3.56)^{*}$ & $(-3.38)^{*}$ & 0.35 & $\mathrm{I}(0)$ & $\mathrm{Y}$ & 0.45 & 0.56 & 2 \\
\hline Small-Medium & $(-3.59)^{*}$ & $(-3.30)^{*}$ & 0.42 & $\mathrm{I}(0)$ & $\mathrm{Y}$ & 2.13 & 1.86 & 2 \\
\hline \multicolumn{9}{|l|}{ Chennai } \\
\hline Nagar and Nagar Old & $(-1.68)^{* * *}$ & $(-1.63)^{* * *}$ & 0.08 & $\mathrm{I}(0)$ & $\mathrm{Y}$ & 1.42 & 0.86 & 2 \\
\hline Small & $(-3.15)^{*}$ & $(-3.13)^{*}$ & 0.29 & $\mathrm{I}(0)$ & $\mathrm{Y}$ & 1.18 & 1.29 & 2 \\
\hline Solapur and Old & $(-1.90)^{* * *}$ & $(-1.67)^{* * *}$ & 0.1 & $\mathrm{I}(0)$ & $\mathrm{Y}$ & 1.64 & 0.89 & 2 \\
\hline
\end{tabular}


